\title{
Ceylon and Rwanda
}

\section{Richard and Maisie Fitter}

Chance took us within the short space of three months to two rather different small countries, Rwanda in December 1973 and Sri Lanka (Ceylon) in January and February 1974, each for about a fortnight. Each country naturally has its wildlife conservation problems, and the differences between these cover such a large part of the spectrum of such problems that it seemed worth while comparing them.

First, however, their similarities. Each country is small and ranks as 'undeveloped' in the current jargon. Each lies in the tropics not far from the Equator. Each is a former European colony, one English, the other French speaking, and each was left as a legacy two national parks. Both are seemingly already overpopulated with a geometrically increasing population; both are intensively cultivated with severe land pressure. Ceylon has a population of $12,750,000$ or 504 to the square mile, Rwanda of $3,297,000$ (1967) or 324 to the square mile. Both are making a genuine effort to conserve their wildlife, not just as a hangover from former colonial rule.

On the other hand there are some sharp differences. Ceylon is an island off the south coast of Asia, with the rather independent outlook one associates with islands. Rwanda is landlocked in Central Africa. Ceylon has an ancient civilisation; Rwanda's traditions are much more recent. Perhaps this is why Ceylon's national parks are heavily used by the inhabitants of the country, Rwanda's largely by expatriates and visitors from overseas, for the same contrast occurs between India and East Africa. Ceylon has declared two new national parks since independence, the 95-sq.-m. Gal Oya in 1954 and the 119-sq.-m. Uda Walawe in 1972. Rwanda has declared none.

Ceylon's two main national parks are Wilpattu on the north-west coast and Ruhunu (often called Yala) on the south-east coast. Wilpattu, now 108,780 hectares (420 sq.-m.), is a largely flat sandy area with natural, mainly freshwater, lakes called villus, surrounded by forest, scrub and dunes. The villus are naturally a focal point for wildlife, especially in the evenings, when we saw many deer including sambur, wild buffalo and crocodiles in or on the edge of the water, leopards not far away, and roosting birds that included herons, pelicans and the dramatic Malabar pied hornbill in some numbers.

Ruhunu is smaller, 23,000 hectares ( 350 sq. m.), rising from sea level to $160 \mathrm{~m}$. (some $500 \mathrm{ft}$ ) with sand dunes on the shore, and scrub and thorn jungle interspersed with large lagoons, the whole area dominated by enormous outcrops of rock. Elephants are numerous - they were there to welcome us at the bungalow's back door when we arrived-and the bird life outstanding, especially of large water birds such as herons, storks and ibises.

The main problems faced by the Wildlife Department are due to 
the heavy use by visitors of two relatively small parks. At Ruhunu their pressure has led the Wildlife Department, despite the opposition of the Ceylon Wildlife and Nature Protection Society, to propose to open a much greater area of the park to visitors, once a new bridge is constructed. Only a small central area (about 100 sq. m.) will remain inviolate. At Wilpattu this option is not open. To outside observers it would seem desirable to consider setting aside more areas as national parks (especially a part of the Sinharaja Forest) and to hasten the development of the two other existing but totally undeveloped parks, Gal Oya and Uda Walawe. It is a fine thing that so many Sri Lanka citizens wish to use their national parks, for this means a public opinion in favour of spending money on the parks. Pressure of increasing population and hence of use of the parks could soon, however, destroy the two small areas now available, and it is imperative, if the parks and their wildlife are to be saved intact, for more space to be made available. The only alternative would be a severe rationing of visits, but if overseas tourism is to be developed in Ceylon, this would involve a most unpopular and undesirable discrimination against Sri Lanka citizens.

Naturally Ceylon has other problems with its parks too. Poaching is always a hazard in any national park, but is not currently serious, judging by the relative tameness of the animals, especially in Ruhunu. A rather special problem is presented by the elephants in Ruhunu and the apparent disappointment of many visitors if they are not 'charged' by one. This leads to what almost amounts to 'baiting' of elephants by some foolish and foolhardy visitors, and needs to be dealt with by an educational campaign, perhaps by giving each visitor a special leaflet on elephants and their habits and educating the drivers of tourist jeeps.

Rwanda's two national parks are the Akagera (formerly Kagera) in the east, on the Tanzanian border, and at one point close to the Ugandan border, and the Parc des Volcans in the north-west, contiguous with the famous Virunga (formerly Albert) Park of Zaïre (the former Congo). These two parks are very different, much more than the two Ceylon parks, from each other. The Akagera Park is largely upland savanna, with marshy valleys, especially in the Kagera River valley along its eastern border. It includes a selection of plains game, of which the commonest are buffalo, Burchell's zebra, hippo, topi and impala; lions are few in number. Sitatunga are there, but not easily seen, and we were fortunate to see a pack of fifteen hunting dogs. Birds are of course abundant. The Parc des Volcans, on the other hand consists essentially of the eastern half of the Virunga Volcano chain (the western half is in Zairre), dramatic mountains rising to over 14,000 feet. Most of the vegetation is woodland or moorland, and its most important animal is the mountain gorilla.

The problems of Akagera are more or less the same as those of any of the East African savanna and open woodland parks. Poaching exists, but appears not to be serious, and the animals are reasonably approachable. The park administration is starved of funds, and has far too little transport to warden the whole area 
properly. The lodge is just outside the park, and is to be extended. If the number of visitors increases greatly, there is some danger that the relatively few existing tracks in the park (there is only one circuit, with offshoots) will be overused.

The Parc des Volcans, on the other hand, is less visited by tourists and almost unwardened. Apart from Dian Fossey and her group of gorilla-research workers at the Karisoke Research Station on the saddle between Visoke and Karisimbe, the great majority of those who enter the park are poachers and illegal graziers with their cattle. A real urgency here (which may have been remedied by the time these words appear in print) is the appointment of a new conservator (already promised) who will send his guards out into the park on patrol. The park has already suffered the loss of an important peripheral area of 10,000 hectares (nearly 25,000 acres) to a pyrethrum-growing scheme sponsored by the EEC. Now the pyrethrum farmers send their cattle to graze in the new peripheral area and only the Karisoke Research Station is doing anything to stop them.

Some means must be found of enabling this park also to contribute tourist income to this very poor country. Tourists will willingly pay to see gorillas at fairly close range, and more could be done to arrange for local guides to take people to see groups of gorillas-not those in the research area of the Karisoke Station-that have been habituated to the presence of strangers, as has already been done at Bukavu in neighbouring Zaïre.

If the problems of Ceylon are those of overuse, in Rwanda the greater problem is that of underuse. In Ceylon there is no danger of the parks being lost, except by tco heavy pressure on a small area, but how long can a small, poor, densely populated country like Rwanda be expected to go on reserving large areas of cultivable land if it does not even bring in a significant revenue from tourists? (In Rwanda even almost perpendicular hillsides are actually cultivated.) It seems to us that while Ceylon is well able to grapple with its own problems, and is clearly doing so, $R$ wanda will need outside help if it is to preserve indefinitely what is, after all, part of the heritage of not only Africa but the world.

One possible way to bring such aid to Rwanda would be to use the device of an international park and to seek the aid of the World Heritage Fund. There can be no doubt that an international park containing the whole of the Virunga Volcanoes range, and so bringing together not only the Parc des Volcans and the Virunga Park but also the contiguous Gorilla Sanctuary in Uganda would be an area of international importance that could justly look to the World Heritage Trust for aid. The Zaïre parks already have a strong cadre of guards and are well patrolled. They could be of great assistance to Rwanda and Uganda if these two countries were willing to internationalise their portions of the Virunga range for this purpose.

Although the Akagera Park is at much less risk than the Parc des Volcans, it too will come under threat if Rwanda's population continues to increase at the present rate, and tourist income does not 
rise. It might be strengthened if Tanzania could be persuaded to join in another international park with the very similar stretch of country on the east side of the Kagera River, which forms Akagera's eastern boundary.

\section{Conclusions}

What conclusions can be drawn from a comparison of the parks of these two small but diverse countries? Perhaps the most important is that wildlife will only survive if people sufficiently want it to. And even then there is a danger that if too many people want to enjoy any particular group of wildlife, they may end by destroying what they want to preserve. In countries where the citizens are too poor or too preoccupied with the earlier stages of advancement towards a level of well-being that can afford the luxury of culture, the outside world must step in with help of some sort if the wildlife is to survive.

\section{FPS Overseas Tours}

Both Rwanda and Ceylon are included in FPS tours in the next year. The first, in July 1974, will combine Rwanda with Zaire (formerly Congo), where the attractions include mountain gorillas; the second, in February 1975, will start in Sri Lanka, visiting both Yala and Wilpattu National Parks, and finish in South India.

\section{Wildlife Photography: a Field Guide, by Eric Hosking and John Gooders. Hutchinson, $£ 2.95$.}

The superb pictures from the camera of Eric Hosking have over many years created interest, knowledge and delight in our wildlife. In recent years John Gooders has stimulated this interest by showing us the work of the world's top wildlife cameramen through the pages of such magazines as Birds of the World. It was perhaps inevitable that a field guide should appear to cover this increasingly practised art; who better qualified to produce it than Hosking and Gooders? For beginners this book will become their bible, but the expert too can always pick up a useful hint from Hosking's experience.

The opening chapter, dealing with cameras and equipment, will assist the beginner to decide how best to spend his money. It is perhaps to be expected that most of this advice is aimed toward the still photographer rather than to ciné, but the film-maker will find much to help in other ways. Throughout, the emphasis on care at all times toward the subject is heavily stressed, and a splendid chapter on ethics will perhaps set the guidelines, or at least give room for thought. The need to obtain permits to photograph certain birds is brought to our attention, but unfortunately the list is incomplete, and it would be wise to obtain a new list before attempting photography. The general information covers all aspects, including hides or the use of sets, how to cope on safari or at the zoo, and is all very sound. To give the book a fresh approach a new set of pictures appear, many taken by Hosking himself; it is a shame therefore that those in black and white should be so poorly reproduced.

One of my own very first books on natural history was Eric Hosking's The Art of Bird Photography. It has given me many years of good advice and $I$ am sure this new field guide will do the same for those just starting out in wildlife photography. 